\title{
The Throes of COVID Melancholia
}

\author{
N Ananthakrishnan
}

\begin{abstract}
The human mankind faced a miserable life due to the ignorance and wrath of the coronavirus. The imposition of lockdowns and restrictions led to job loss and global recessions. A ray of hope after the first wave was due to the vaccine's arrival, but yet there was hesitancy due to suspicions and rumors. The virus had come back with full vigor during the second wave with countless pyres burned. The country faced a severe crisis in terms of a shortage of vaccines, drugs, beds, and oxygen. Still, it is not known when this would end-all will be well only when the human mankind works as one.
\end{abstract}

Keywords: Coronavirus, Job loss, Lockdowns, Vaccines.

Pondicherry Journal of Nursing (2021): 10.5005/jp-journals-10084-13117

A year and a half ago it was, when Covid 19 showed its face, From bats, apparently, the virus to humans made its way, Very soon it seemed to better like its new found race, No matter how it started, mankind began its deadly race that day.

Ignorance of the virus' path ruled the roost, It began with lockdowns lasting for weeks and months, Handwashing, masking, social distancing got a boost, Still, millions got infected in spite of forced "bandhs."

Little by little, knowledge gained, light at last shone, On methods of preventing the spread of the beast, Still, Jobs lost, massive migrations, deaths full blown, The world was rocked while the virus had a human feast.

Headless chicken became the Homo sapiens race, Anxious eyes, wrinkled foreheads, ears ringed by mask strings, As the world went round and round with covered face, Nowhere to go, it seemed the world had lost its wings.

Came September '20, we seemed to get our bearings back, For the first time, daily infected numbers seemed to slack, It appeared that life was not all that gloomy, bleak and black Light at the end of the tunnel one hoped would come back.

Then came the promise of hordes of vaccines, Suspicions, rumors galore, led to vaccine hesitancy, Endless fears, overconfidence, countless controversies, Hence, demand became slack with no signs of buoyancy.

The world relaxed, all restrictions abandoned, Came back the virus with regained strength, The old scenes rewound, hospitals full, countless pyres burned, Stretching queues at hospitals, gained in length.

Had humans lost their collective minds, Massive rallies, no precautions to be seen, As the political jamboree endlessly winds, No one cares, it's as if the past has never been.
Dean of Faculty, Sri Balaji Vidyapeeth (Deemed to be University), Puducherry, India

Corresponding Author: N Ananthakrishnan, Dean of Faculty, Sri Balaji Vidyapeeth (Deemed to be University), Puducherry, India, Phone: +91 9443284265, e-mail: n.ananthk@gmail.com

How to cite this article: Ananthakrishnan N. The Throes of COVID Melancholia. Pon J Nurs 2021;14(3):73.

Source of support: Nil

Conflict of interest: None

Vaccine hesitancy gave place to vaccine craving,

Too little, too late, no drug available for the jab,

Vaccine shortage led in desperation to crowds leaving,

Only to go in vain to another place, another center, another lab.

New scenarios and as yet unexplored track,

In a country of excess production, deaths due to oxygen lack, What a pity, that trucks were stopped at borders for men to sack, The breath of life became a target for some to steal and hack.

No one knows, when, if at all, it will end,

Rulers are mad, men have lost the trend,

When can one say we have crossed the bend?

Or must one wait for God to come and mend.

We have seen chaos, political jamborees, indifferent governance, Selfishness, hoarding, and black marketing of drugs, Lack of coordination, mismanagement beyond remembrance, Realization has come too late, mankind to fix has many bugs.

There are lessons to learn, time for sanity to return,

"All will be well" only when there is wellness for "each and everyone,"

No man is an island said the great poet John Donne, For the world to be healthy, mankind must work as one.

(-) The Author(s). 2021 Open Access This article is distributed under the terms of the Creative Commons Attribution 4.0 International License (https://creativecommons [2]. org/licenses/by-nc/4.0/), which permits unrestricted use, distribution, and non-commercial reproduction in any medium, provided you give appropriate credit to the original author(s) and the source, provide a link to the Creative Commons license, and indicate if changes were made. The Creative Commons Public Domain Dedication waiver (http://creativecommons.org/publicdomain/zero/1.0/[3]) applies to the data made available in this article, unless otherwise stated. 